Article

\title{
Growth Restriction of Rhizoctonia solani via Breakage of Intracellular Organelles Using Crude Extracts of Gallnut and Clove
}

\author{
Jian Wang ${ }^{1,2,3,+}$, Xianfeng Hu ${ }^{1,3,+}$, Chenglong Yang ${ }^{2,+}$, Xiaomao Wu ${ }^{1,3}$, Rongyu Li ${ }^{1,3, *}$ and Ming Li ${ }^{1,3, *}$ \\ 1 Institute of Crop Protection, Guizhou University, Guiyang 550025, China; Wangj_ian@sina.com (J.W.); \\ huxianfenggzu@163.com (X.H.); wuxm827@126.com (X.W.) \\ 2 Institute of Subtropical Crops, Guizhou Academy of Agricultural Sciences, Xingyi 562400, China; \\ yangchenglong208@163.com \\ 3 The Provincial Key Laboratory for Agricultural Pest Management in Mountainous Region, Guizhou \\ University, Guiyang 550025, China \\ * Correspondence: lirongyu0328@126.com (R.L.); lm21959@163.com (M.L.); Tel.: +86-15185148063 (R.L.); \\ +86-13885101658 (M.L.) \\ + These authors contributed equally to this work.
}

Citation: Wang, J.; Hu, X.; Yang, C.; Wu, X.; Li, R.; Li, M. Growth

Restriction of Rhizoctonia solani via Breakage of Intracellular Organelles Using Crude Extracts of Gallnut and Clove. Molecules 2021, 26, 1667. https://doi.org/10.3390/ molecules 26061667

Academic Editor: Raffaele Capasso

Received: 21 February 2021

Accepted: 12 March 2021

Published: 17 March 2021

Publisher's Note: MDPI stays neutral with regard to jurisdictional claims in published maps and institutional affiliations.

Copyright: (c) 2021 by the authors. Licensee MDPI, Basel, Switzerland. This article is an open access article distributed under the terms and conditions of the Creative Commons Attribution (CC BY) license (https:/ / creativecommons.org/licenses/by/ $4.0 /)$.

\begin{abstract}
Plant diseases reduce crop yield and quality, hampering the development of agriculture. Fungicides, which restrict chemical synthesis in fungi, are the strongest controls for plant diseases. However, the harmful effects on the environment due to continued and uncontrolled utilization of fungicides have become a major challenge in recent years. Plant-sourced fungicides are a class of plant antibacterial substances or compounds that induce plant defenses. They can kill or inhibit the growth of target pathogens efficiently with no or low toxicity, they degrade readily, and do not prompt development of resistance, which has led to their widespread use. In this study, the growth inhibition effect of 24 plant-sourced ethanol extracts on rice sprigs was studied. Ethanol extract of gallnuts and cloves inhibited the growth of bacteria by up to $100 \%$. Indoor toxicity measurement results showed that the gallnut and glove constituents inhibition reached $39.23 \mu \mathrm{g} / \mathrm{mL}$ and $18.82 \mu \mathrm{g} / \mathrm{mL}$, respectively. Extract treated rice sprigs were dry and wrinkled. Gallnut caused intracellular swelling and breakage of mitochondria, disintegration of nuclei, aggregation of protoplasts, and complete degradation of organelles in hyphae and aggregation of cellular contents. Protection of Rhizoctonia solani viability reached $46.8 \%$ for gallnut and $37.88 \%$ for clove in water emulsions of $1000 \mu \mathrm{g} / \mathrm{mL}$ gallnut and clove in the presence of $0.1 \%$ Tween 80 . The protection by gallnut was significantly stronger than that of clove. The data could inform the choice of plant-sourced fungicides for the comprehensive treatment of rice sprig disease. The studied extract effectively protected rice sprigs and could be a suitable alternative to commercially available chemical fungicides. Further optimized field trials are needed to effectively sterilize rice paddies.
\end{abstract}

Keywords: Rhus chinensis Mill; Syzygium aromaticum; rice sheath blight; antifungal activity

\section{Introduction}

Rice sheath blight, known as Moire disease, is one of the most serious fungal diseases or rice crops globally [1,2]. Sheath blight, caused by Rhizoctonia solani Kühn AG1 1A (teleomorph Thanatephorus cucumeris (A. B. Frank) Donk), is one of the most important diseases in rice worldwide [3,4]. Rice sheath blight affects both the quality and yield of rice. The prevalence if rice sheath blight is increasing in China, reflecting changes in rice farming that include increased planting density and lack of high resistance varieties. In high-temperature and humid environments, rice sheath blight has reduced rice yields by up to 50\% [2-5]. Rice sheath blight hosts are widespread and the fungus core can survive for a long time in the soil, with a high rate of genetic variation. These factors make it difficult to control the disease in the production process [6]. 
The lack of rice varieties with high resistance to rice sheath blight complicates the prevention and treatment. Current measures are mainly chemical and most commonly include tyrutin and mimide fluoroazoles. Jinggangmycin, which is produced from waterabsorbing streptomycin bacteria, is most commonly used in China $[7,8]$. Resistance was first described in Zhengzhou County, Henan Province [9]. The field statistical resistance rate of Fujian Province reached $2.48 \%$ in 2015 [10]. Surveillance of jinggangmycin resistance in 206 rice sheath blight strains in 26 districts of 12 cities found that the strains became resistant, with increasing dosages required year-by-year [11,12]. Additional new problems, including environmental pollution, deterioration of human health, damage to non-target organisms in the field, destruction of the ecological balance of rice paddies, and serious problems caused by the utilization of jinggangmycin, led the European Union to ban the use of jinggangmycin in 2002 (The Commission of European Communities, No. 2076/2002). Accordingly, there is a need for plant-sourced environmentally friendly pesticides with high efficiency, low toxicity, and broad spectrum activity.

Important facets of biosynthetic pesticides attributed to plant-sourced pesticides include high efficiency, low or no toxicity, easy degradation, and lack of development of resistance to drugs. Antibacterial substances in plants or the induction of plant defenses can kill or inhibit the growth of pathogenic bacteria. More than 500,000 plant species have been identified globally. However, only about $10 \%$ of known plants' chemical compositions have been analyzed [13]. Grange et al. reported that 2400 plants have active ingredients for pest control [14]. Plant resources are extraordinarily rich in China, with more than 10,000 kinds of Chinese herbal medicine resources, 1400 kinds of plants with inhibitory activity, and over 328,000 plant-based natural compounds $[13,15]$. Fogliani studied the antibacterial activity of 50 species of fire-barrel tree plants from Scotland and reported that 49 inhibited spores to varying extents [16]. Ojala et al. showed that extracts of wrinkled parsley and fennel have antibacterial effects on antiseptic sclerosis [17]. Srinivasan et al. studied the antibacterial activity of 50 medicinal plant water products in India and found that 36 of the plants had antibacterial activity and 12 had broad spectrum antibacterial effects [18].

Plant-sourced fungicides are an important part of biorational pesticides and have become the focus of the current research. In this study, the growth inhibition effect of 24 plant-sourced active compounds on the growth of mycelia of rice sheath blight was studied. Indoor toxicology and viability protection studies revealed that gallnut and clove protected rice by inhibiting the mycelial growth of rice sheath blight. Further inhibition mechanisms were investigated by transmission electron microscopy and scanning electron microscopy. These findings demonstrated that internal cell structures of rice sheath blight were destroyed and the internal milieu was disordered. The results should inform new research strategies for the prevention and control of rice sheath blight and are expected to lead to the development of new botanical fungicides.

\section{Results}

\subsection{Inhibition of R. solani Plant-Derived Extracts}

The biological control efficiency of 24 plant ethanol extracts against $R$. solani was analyzed at room temperature (Table 1). The incidence and inhibition percentage of all plant-based ethanol extracts were analyzed. The 24 plant ethanol extracts tested at a concentration of $10 \mathrm{mg} / \mathrm{mL}$ showed varying degrees of inhibition of $R$. solani. The inhibition effect of the ethanol extract of gallnut and cloves was the best, with antibacterial rates of $100 \%$. They were followed by the ethanol extracts of Chinese angelica and Cinnamon, with rates of $51.31 \%$ and $66.99 \%$, respectively. The remaining ethanol extracts produced rates with a content of $<30 \%$. Gallnut and clove extracts were selected for further analyses. 
Table 1. Inhibition effects of ethanol extracts from plants against R.solani.

\begin{tabular}{|c|c|c|c|c|}
\hline Plants Resources & Families & Extract Position & Colony Diameter (cm) & Inhibition Ratio (\%) \\
\hline $\begin{array}{l}\text { Angelica dahurica (Fisch. ex Hoffm.) } \\
\text { Benth. et Hook. f. ex Franch. et Sav }\end{array}$ & Apiaceae Lindl. & root & $(6.07 \pm 0.12)^{d}$ & 4.56 \\
\hline $\begin{array}{c}\text { Angelica pubescens Maxim. f. biserrata } \\
\text { Shan et Yuan }\end{array}$ & Apiaceae Lindl. & root & $(3.42 \pm 0.23)^{\circ}$ & 38.93 \\
\hline Angelica sinensis & Apiaceae Lindl. & root & $(2.98 \pm 0.2) \mathrm{q}$ & 51.31 \\
\hline Atractylodes macrocephala Koidz. & Asteraceae Bercht. \& J. Presl & rhizome & $(4.28 \pm 0.37)^{n}$ & 23.57 \\
\hline Cinnamomum cassia Presl & Lauraceae Juss. & bark & $(2.02 \pm 0.03)^{r}$ & 66.99 \\
\hline Cnidium monnieri (L.) Cuss. & Apiaceae Lindl. & fruit & $(4.58 \pm 0.11)^{\mathrm{kl}}$ & 24.55 \\
\hline Coptis chinensis Franch. & Ranunculaceae Juss. & total plant & $(3.3 \pm 0.17)^{p}$ & 41.07 \\
\hline Crataegus pinnatifida Bunge & Rosaceae Juss. & fruit & $(4.35 \pm 0.19) \mathrm{mn}$ & 22.32 \\
\hline Cynanchum otophyllum & Paeoniaceae Raf. & root & $(6.45 \pm 0.02)^{c}$ & - \\
\hline Eucommia ulmoides Oliver & Eucommiaceae Engl. & bark & $(5.4 \pm 0.02)^{g}$ & 15.09 \\
\hline Forsythia suspensa & Oleaceae & fruit & $(4.62 \pm 0.26)^{\mathrm{k}}$ & 17.5 \\
\hline Glycyrrhiza uralensis Fisch. & Fabaceae Lindl. & rhizoma & $(5.28 \pm 0.015)^{h}$ & 13.73 \\
\hline Heartleaf Houttuynia Herb & Saururaceae Rich. ex T. Lestib. & leaves & $(6.58 \pm 0.21)^{b}$ & - \\
\hline Isatis tinctoria & Brassicaceae Burnett & rhizoma & $(6.8 \pm 0.16)^{a}$ & - \\
\hline Mentha haplocalyx Briq. & Labiatae & leaves & $(4.42 \pm 0.02)^{\mathrm{m}}$ & 21.07 \\
\hline Morus alba L. & Moraceae Gaudich. & shoot & $(5.02 \pm 0.17)^{j}$ & 10.36 \\
\hline Reynoutria japonica Houtt. & Polygonaceae & rhizome & $(5.62 \pm 0.05)^{\text {ef }}$ & 11.64 \\
\hline Rheum palmatum $\mathrm{L}$. & Polygonaceae & rhizoma & $(4.5 \pm 0.29)^{1}$ & 29.25 \\
\hline Rhizoma Pinelliae & Araceae Juss. & stem tuber & $(5.22 \pm 0.11)^{h}$ & 6.79 \\
\hline Rhus chinensis Mill. & Anacardiaceae R. Br. & Galls on leaves & $(0)^{s}$ & 100 \\
\hline Salvia miltiorrhiza Bunge & Labiatae & root & $(5.07 \pm 0.53)^{\mathrm{i}}$ & 20.28 \\
\hline $\begin{array}{c}\text { Saposhnikovia divaricata (Trucz.) } \\
\text { Schischk. }\end{array}$ & Apiaceae Lindl. & root & $(5.63 \pm 0.17)^{\mathrm{e}}$ & 7.24 \\
\hline Syzygium aromaticum (L.) Merr. EtPerry & Myrtaceae Juss. & fruit & $(0) \mathrm{s}$ & 100 \\
\hline Xanthium sibiricum Patrin ex Widder & Asteraceae Bercht. \& J. Presl & fruit & $(5.54 \pm 0.05)^{f}$ & 8.73 \\
\hline
\end{tabular}

Notes: Data in the table are mean value \pm standard deviation. The different letters in the same column indicate significant differences at the 0.05 levels. Positive control: Jinggangmycin $\mathrm{EC}_{50}=206.76 \mu \mathrm{g} / \mathrm{mL}$; Negative control: Sterile water.

\subsection{Indoor Toxicity Test of Plant-Derived Extracts against R. solani}

Indoor toxicity tests were performed for the ethanol extracts of cloves and gallnut, because both completely inhibited $R$. solani at a concentration of $10 \mathrm{mg} / \mathrm{mL}$. When the concentration of the ethanol extracts ranged from 10 to $75 \mu \mathrm{g} / \mathrm{mL}$, the inhibition rate of ethanol extracts of clove at $50 \mu \mathrm{g} / \mathrm{mL}$ was $89.85 \%$, and gallnut ethanol extract at $50 \mu \mathrm{g} / \mathrm{mL}$ was only $77.66 \%$. The findings demonstrated that a low concentration of ethanol extract of clove effectively inhibited $R$. solani mycelium. With increasing extract concentration, a significant difference between the two extracts was observed $(p<0.05$, Table 2, Figure 1).

Table 2. Indoor toxicity of ethanol extracts from two plants to R. solani.

\begin{tabular}{|c|c|c|c|c|c|}
\hline \multirow{2}{*}{$\begin{array}{l}\text { Concentration } \\
(\mu \mathrm{g} / \mathrm{mL})\end{array}$} & \multicolumn{2}{|c|}{ The Ethanol Extracts from Clove } & \multirow{2}{*}{$\begin{array}{c}\text { Concentration } \\
(\mu \mathrm{g} / \mathrm{mL})\end{array}$} & \multicolumn{2}{|c|}{ The Ethanol Extracts from Gallnut } \\
\hline & Colony Diameter (cm) & Inhibition Ratio (\%) & & Colony Diameter (cm) & Inhibition Ratio (\%) \\
\hline 0 & $(6.85 \pm 0.1)^{\mathrm{a}}$ & - & 0 & $(6.85 \pm 0.1)^{a}$ & - \\
\hline 10 & $(5.62 \pm 0.2)^{b}$ & 17.96 & 15 & $(6.56 \pm 0.07)^{b}$ & 4.23 \\
\hline 20 & $(3.85 \pm 0.2)^{c}$ & 43.8 & 30 & $(3.75 \pm 0.1)^{c}$ & 45.26 \\
\hline 30 & $(2.69 \pm 0.12)^{d}$ & 60.73 & 45 & $(3.22 \pm 0.11)^{d}$ & 52.99 \\
\hline 40 & $(1.38 \pm 0.11)^{\mathrm{e}}$ & 79.85 & 60 & $(2.7 \pm 0.05)^{\mathrm{e}}$ & 60.29 \\
\hline 50 & $(0.68 \pm 0.15)^{f}$ & 89.49 & 75 & $(1.57 \pm 0.03)^{f}$ & 77.66 \\
\hline
\end{tabular}

Notes: Data in the table are mean value \pm standard deviation. The different letters in the same column indicate significant differences at the 0.05 level. 


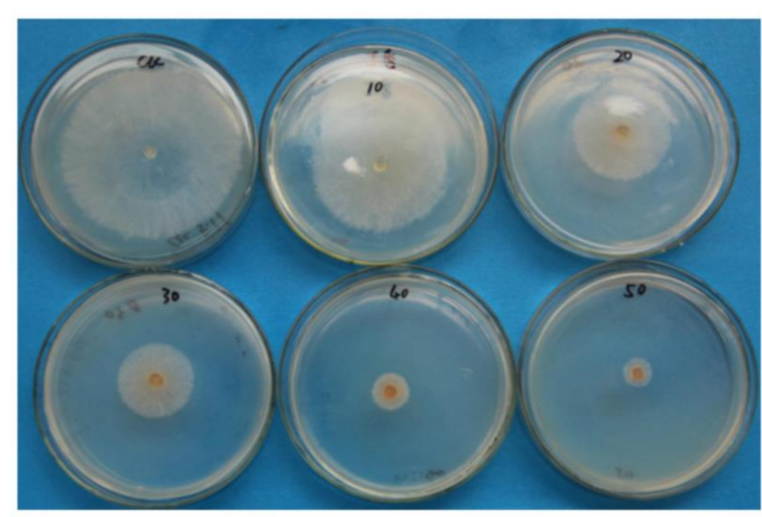

(a)

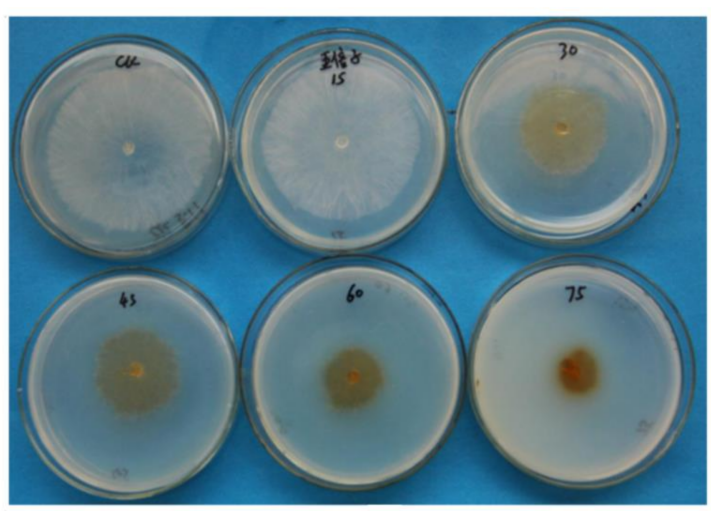

(b)

Figure 1. (a) The ethanol extracts from clove at concentrations from 10 to $50 \mu \mathrm{g} / \mathrm{mL}$; (b) the ethanol extracts from gallnut at concentrations from 15 to $75 \mu \mathrm{g} / \mathrm{mL}$.

Statistical analysis of the data revealed a significant linear relationship between the concentration of the extract and the inhibition rate, with correlation coefficients of 0.9678 for gallnut and 0.9593 for clove. The $\mathrm{EC}_{50}$ values of the ethanol extracts of gallnut and clove against $R$. solani were 41.84 and $21.68 \mu \mathrm{g} / \mathrm{mL}$, respectively. The $E_{75}$ values was 72.59 and $36.34 \mu \mathrm{g} / \mathrm{mL}$, respectively. The results showed that both gallnut and clove extracts showed good effects (Table 3).

Table 3. Toxic regression equations of ethanol extracts from two plants to $R$. solani.

\begin{tabular}{ccccc}
\hline Plants & Toxic Regression Equation $(\mathrm{Y}=\mathrm{A}+\mathbf{B} \times \mathbf{X})$ & Correlation Coefficient & $\mathrm{EC}_{50}(\mu \mathrm{g} / \mathrm{mL})$ & $\mathrm{EC} \mathbf{7 5}_{(}(\boldsymbol{\mu g} / \mathrm{mL})$ \\
\hline gallnut & $\mathrm{Y}=-0.6717+3.5590 \mathrm{x}$ & 0.9678 & 41.84 & 72.59 \\
clove & $\mathrm{Y}=0.0250+3.9031 \mathrm{x}$ & 0.9593 & 21.68 & 36.34 \\
\hline
\end{tabular}

\subsection{Effects of Ethanol Extracts from Clove and Gallnut on Mycelial Morphology of R. solani}

The colony morphology of $R$. solani treated with different concentrations of ethanol extracts of gallnut and clove changed significantly. Scanning electron microscopy (SEM) revealed that the mycelia of the control treatment were uniform in diameter with a smooth surface, good extension, and complete secondary mycelium growth (Figure 2a,b). In contrast, a $24 \mathrm{~h}$ treatment with $20 \mu \mathrm{g} / \mathrm{mL}$ clove extract produced seriously shriveled mycelia with thinner growth point of secondary mycelium (Figure 2c,d). After treatment with $40 \mu \mathrm{g} / \mathrm{mL}$ gallnut extract (Figure 2e,f) for $24 \mathrm{~h}$, the mycelium of $R$. solani was deformed, shriveled, and folded, and the thickness was uneven. The growth point of the secondary mycelium was damaged and folded. Both extracts produced shriveled and shrivel mycelia. The effect of the clove ethanol extract at low concentrations was more pronounced than that of gallnut ethanol extract.

\subsection{Effects of Ethanol Extracts from Clove and Gallnut on Ultrastructure of Mycelia of Rice Sheath Blight}

The mycelia of $R$. solani treated with ethanol extracts of gallnut and clove displayed significant changes in morphology and profound damage of cell ultrastructure. In particular, the permeability of mycelial cells and the structure and morphology of organelles, such as the cytoplasm and mitochondria, were significantly altered, as shown in Figure 3. The cell morphology of the control (Figure $3 a, b)$ was regular and the structure was complete. The cell wall was uniform in texture and thickness, and was closely linked to the cell membrane. The protoplast was dense and uniform. The mitochondria, endoplasmic reticulum, vacuole, and other structures were clear and complete. Mycelia treated with $72.59 \mu \mathrm{g} / \mathrm{mL}$ gallnut ethanol extract displayed swelling and rupture of mitochondria, disintegrated nuclei, and aggregation of protoplasts (Figure 3c,d; Table 3). The organelles 
in mycelia treated with $36.34 \mu \mathrm{g} / \mathrm{mL}$ ethanol extract of clove were completely degraded with aggregated cell contents (Figure 3e,f; Table 3).

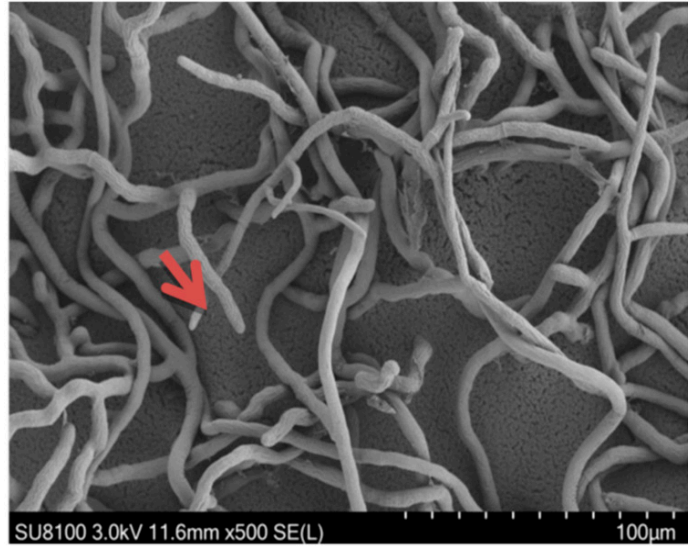

(a)

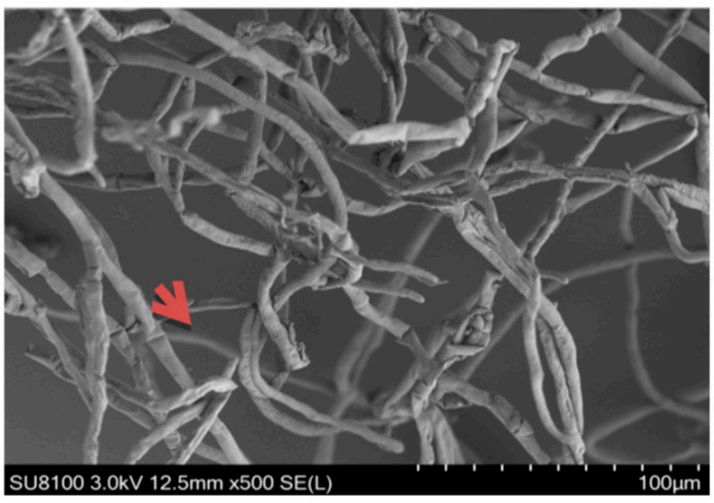

(c)

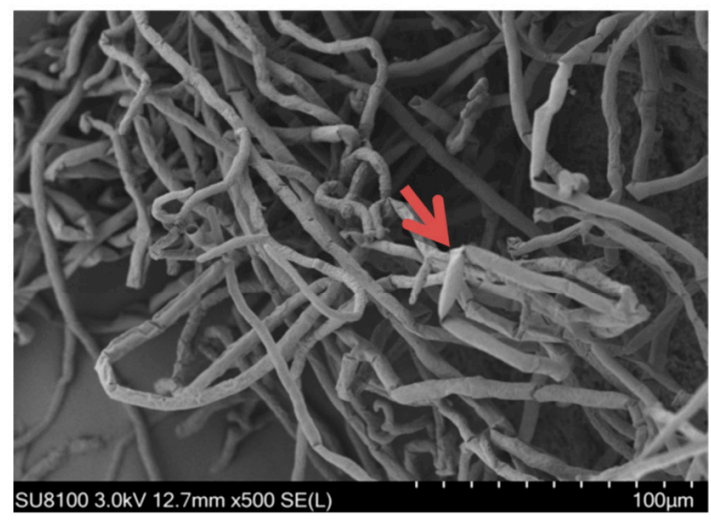

(e)

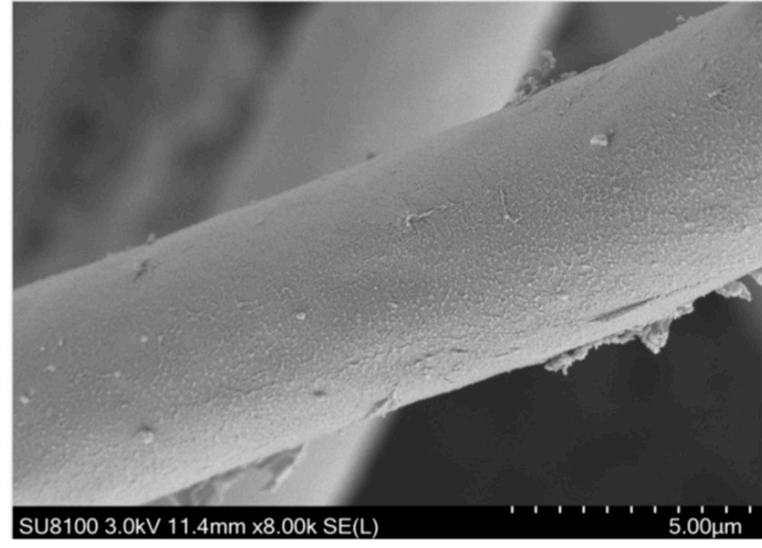

(b)

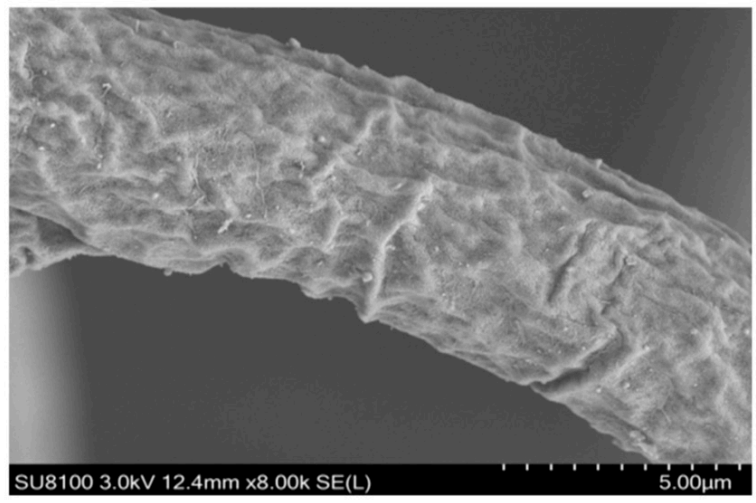

(d)

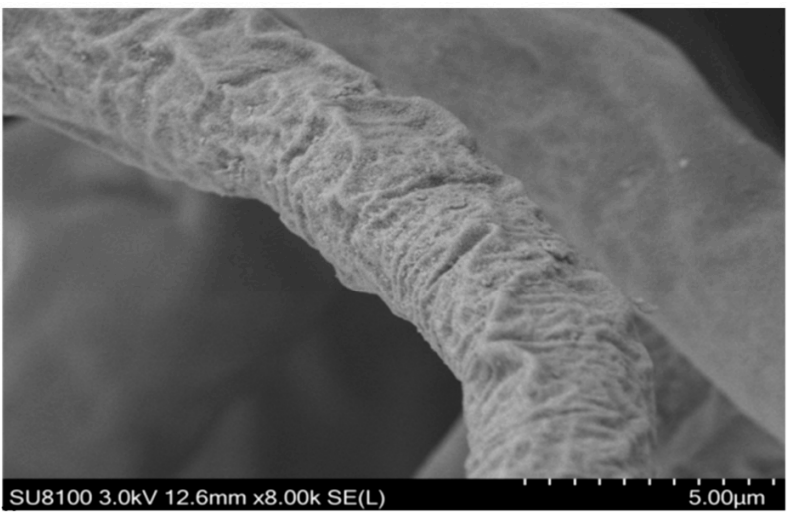

(f)

Figure 2. Scanning electron micrographs (SEM) of $R$. solani: hyphae exposed to the ethanol extracts from two $R$. solani at concentrations of $(\mathbf{a}, \mathbf{b}) 0 \mu \mathrm{g} / \mathrm{mL}$ and $(\mathbf{c}, \mathbf{d}) \mathrm{EC}_{75}=36.34 \mu \mathrm{g} / \mathrm{mL}$; the ethanol extracts from clove, $(\mathbf{e}, \mathbf{f}) \mathrm{EC}_{75}=72.59 \mu \mathrm{g} / \mathrm{mL}$; the ethanol extracts from gallnut. Arrows and arrowheads indicate hyphae shrinkage and partial distortion. 


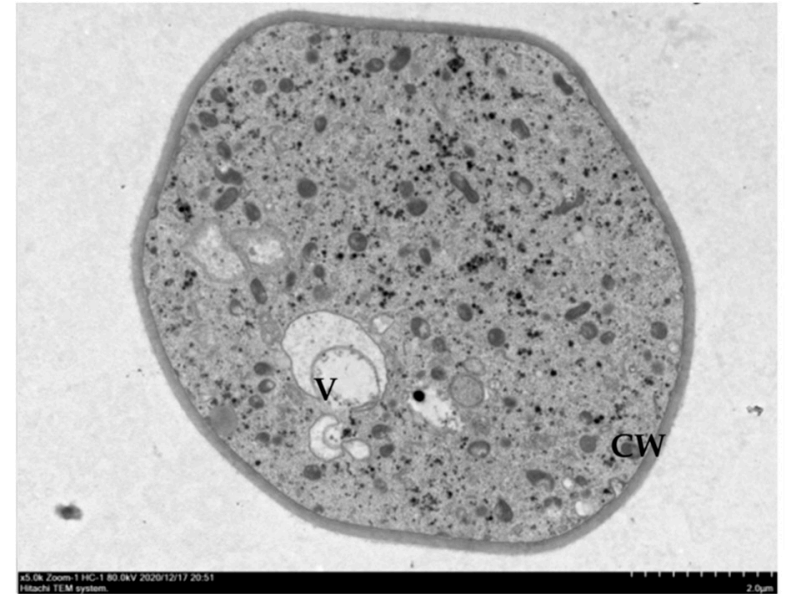

(a)

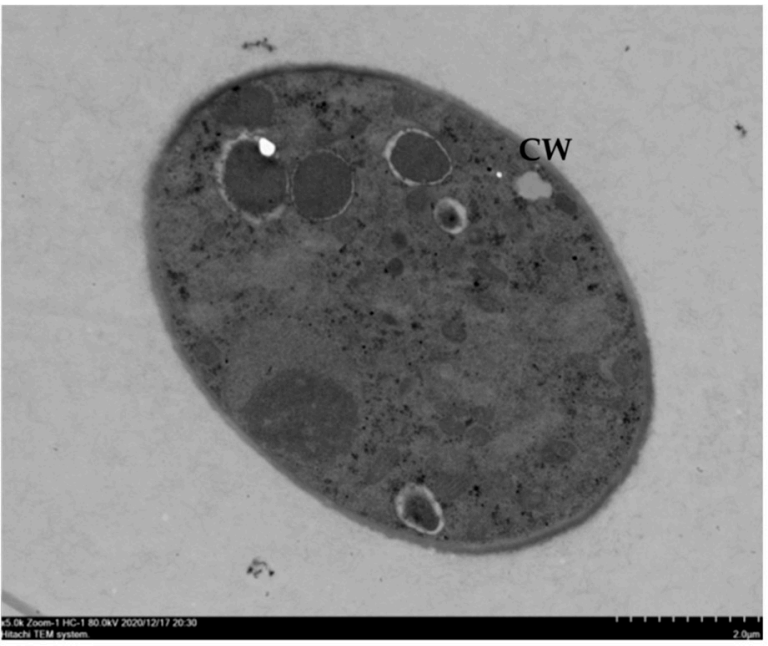

(c)

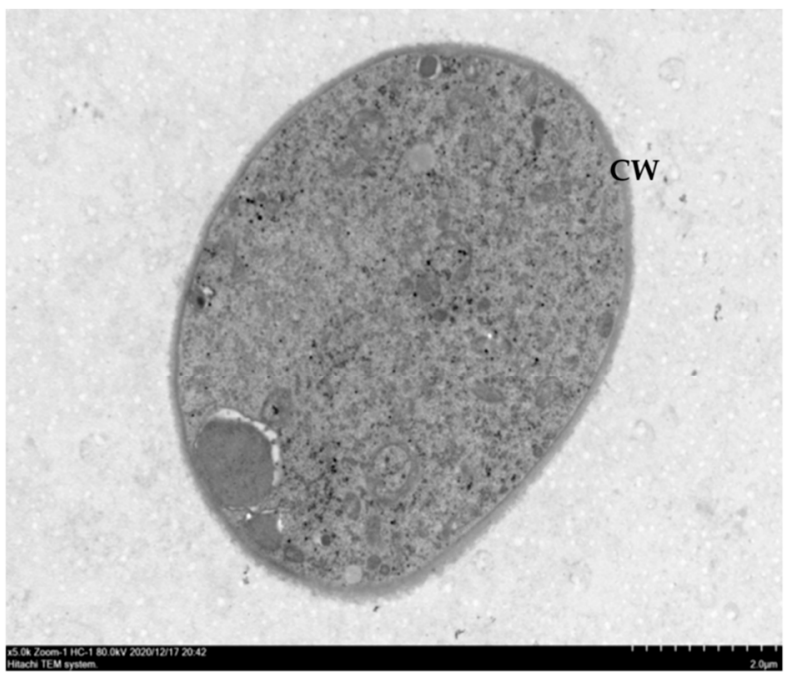

(e)

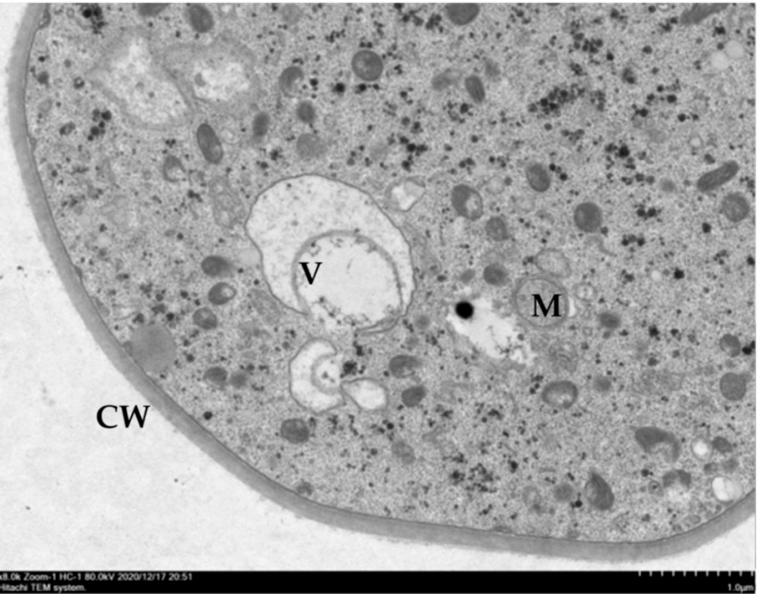

(b)

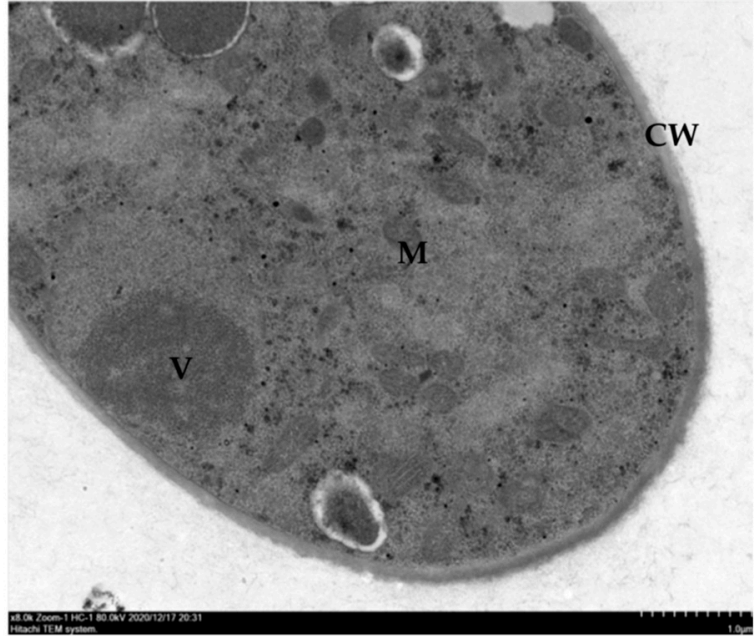

(d)

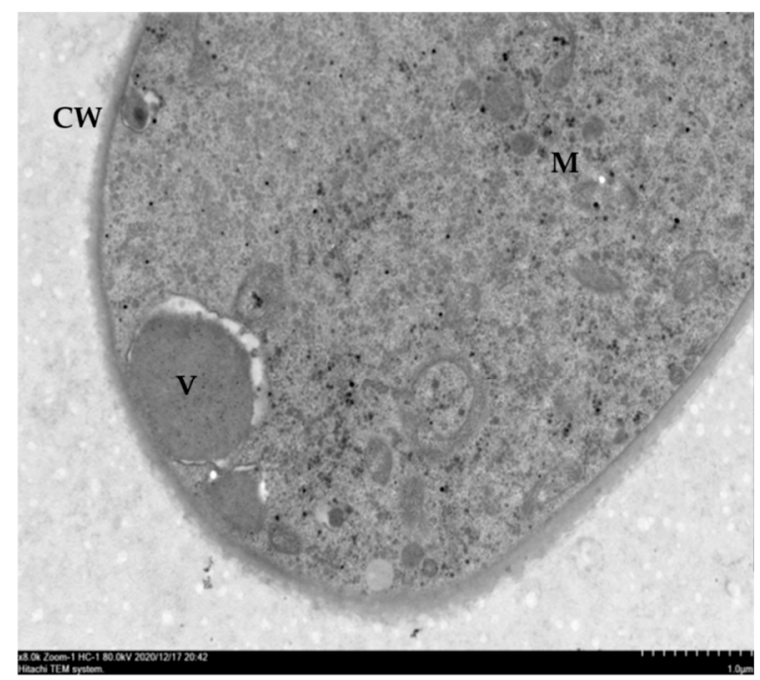

(f)

Figure 3. Transmission electron micrographs of $R$. solani hyphae, where hyphae was exposed to the ethanol extracts from two plant at concentrations of $(\mathbf{a}, \mathbf{b}) 0 \mu \mathrm{g} / \mathrm{mL} ;(\mathbf{c}, \mathbf{d}) E_{75}=72.59 \mu \mathrm{g} / \mathrm{m}$, the ethanol extracts from gallnut; and (e,f) $\mathrm{EC}_{75}=36.34 \mu \mathrm{g} / \mathrm{mL}$, the ethanol extracts from clove, $\mathrm{L} ; \mathrm{CW}=$ cell wall. 


\subsection{Protective Effects of Clove and Gallnut Ethanol Extracts on Rice In Vivo}

The control effect increased as the concentration of the ethanol extracts of gallnut and clove increased. The control effect of gallnut reached $46.80 \%$ when the ethanol extract concentration ranged between 200 and $1000 \mu \mathrm{g} / \mathrm{mL}$. The value for clove was only $37.88 \%$ at the same concentration range. The control effect of gallnut ethanol extract was $8.92 \%$ higher than that of clove at $1000 \mu \mathrm{g} / \mathrm{mL}$. Thus, although the clove ethanol extract showed a good inhibitory effect on $R$. solani, it did not show a good control effect on rice plants (Table 4, Figure 4).

Table 4. Biocontrol efficiency of ethanol extracts from gallnut and clove against rice sheath blight pathogen $R$. solani under green house condition.

\begin{tabular}{cccccc}
\hline Treatment & $\begin{array}{c}\text { Ethanol Extract from Gallnut } \\
\text { Disease Index }\end{array}$ & $\begin{array}{c}\text { Ethanol Extract from Clove } \\
\text { Disease Suppression (\%) }\end{array}$ & Treatment & $\begin{array}{c}\text { Disease Index } \\
\text { Disease Suppression (\%) }\end{array}$ \\
\hline 0 & 3.59 & & 0 & 3.59 & $9.19^{\mathrm{e}}$ \\
$200 \mu \mathrm{g} / \mathrm{mL}$ & 2.92 & $18.66^{\mathrm{e}}$ & $200 \mu \mathrm{g} / \mathrm{mL}$ & 3.26 & $17.55^{\mathrm{d}}$ \\
$400 \mu \mathrm{g} / \mathrm{mL}$ & 2.75 & $23.40^{\mathrm{d}}$ & $400 \mu \mathrm{g} / \mathrm{mL}$ & 2.96 & $21.17^{\mathrm{c}}$ \\
$600 \mu \mathrm{g} / \mathrm{mL}$ & 2.47 & $31.20^{\mathrm{c}}$ & $600 \mu \mathrm{g} / \mathrm{mL}$ & 2.83 & $28.69^{\mathrm{b}}$ \\
$800 \mu \mathrm{g} / \mathrm{mL}$ & 2.32 & $35.38^{\mathrm{b}}$ & $800 \mu \mathrm{g} / \mathrm{mL}$ & 2.56 & $37.88^{\mathrm{a}}$ \\
$1000 \mu \mathrm{g} / \mathrm{mL}$ & 1.91 & $46.80^{\mathrm{a}}$ & $1000 \mu \mathrm{g} / \mathrm{mL}$ & 2.23 & \\
\hline
\end{tabular}

Notes: Data in the table are mean value \pm standard deviation. The different letters in the same column indicate significant differences at the 0.05 levels.

\section{$200 \mu \mathrm{g} / \mathrm{mL} 400 \mu \mathrm{g} / \mathrm{mL} 600 \mu \mathrm{g} / \mathrm{mL} 800 \mu \mathrm{g} / \mathrm{mL} 1000 \mu \mathrm{g} / \mathrm{mL}$}
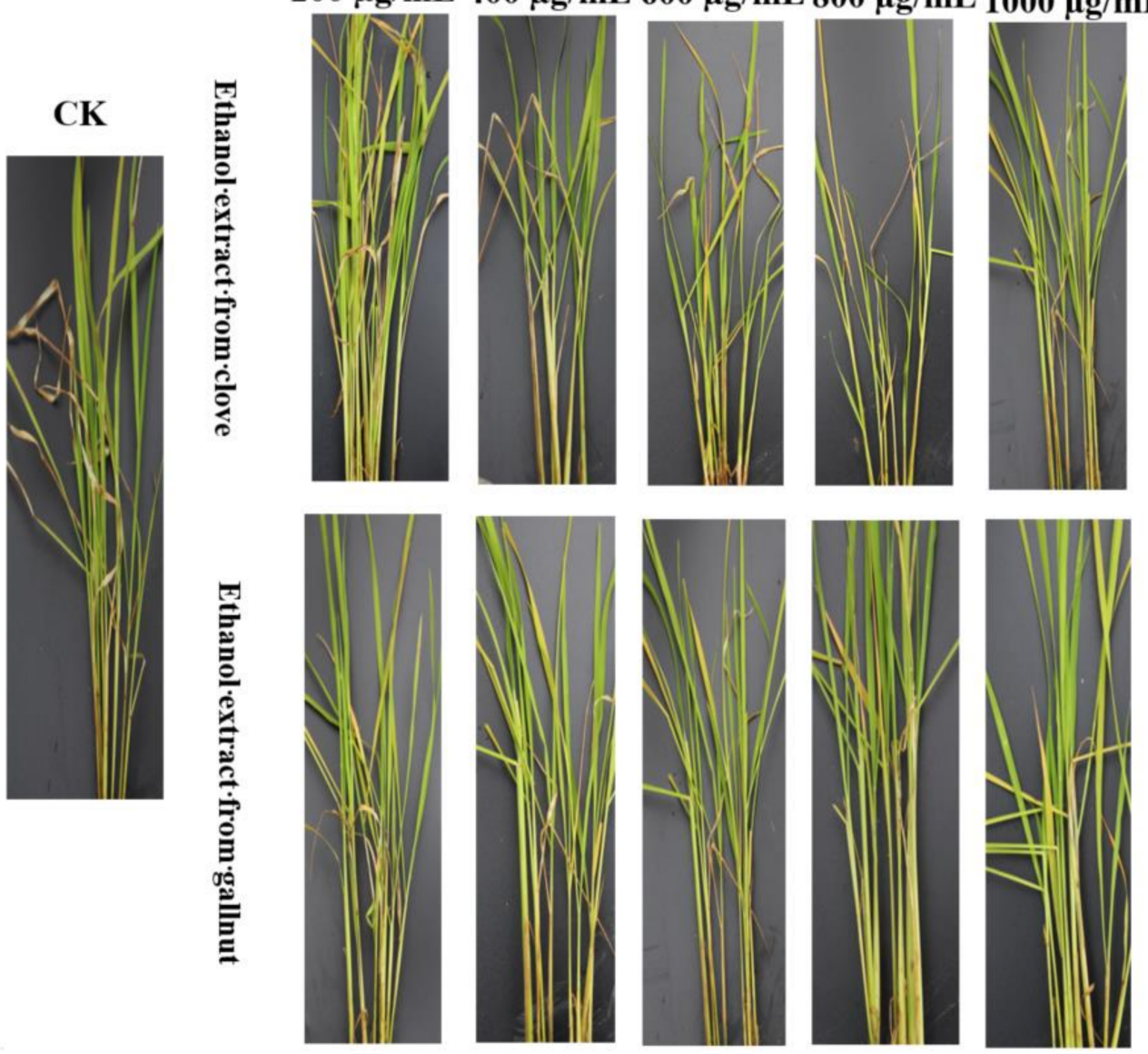

Figure 4. Effect of ethanol extracts from two Chinese herbs on the rice sheath blight. CK: Not treated with drug; The ethanol extracts of gallnut and clove were of different concentrations: $200 \mu \mathrm{g} / \mathrm{mL}$, $400 \mu \mathrm{g} / \mathrm{mL}, 600 \mu \mathrm{g} / \mathrm{mL}, 800 \mu \mathrm{g} / \mathrm{mL}, 800 \mu \mathrm{g} / \mathrm{mL}, 1000 \mu \mathrm{g} / \mathrm{mL}$. 


\subsection{LC-MS and Data Analysis}

The quantitative ion chromatogram of lauric acid was obtained by liquid chromatographymass spectrometry (Figure 5a). The peak time of lauric acid was about $7.584 \mathrm{~min}$, the regression equation was $\mathrm{Y}=327,272.248 \mathrm{x}-254,692.2965$, and the correlation coefficient was 0.9987 , which indicated that there was a good linear relationship between the concentration and the corresponding peak area in the concentration range of $10-100 \mu \mathrm{gmL}$. The lauric acid content in the ethanol extract of gallnut $(10 \mathrm{mg} / \mathrm{mL})$ was $1.39 \mathrm{mg} / \mathrm{mL}$, Therefore, the lauric acid content in ethanol extracts of Galla chinensis is about $13.9 \%$.

The quantitative ion chromatogram (Figure $5 b$ ) of eugenol was obtained by liquid chromatography-mass spectrometry. The peak time of eugenol was $4.012 \mathrm{~min}$. The regression equation was $Y=67,959 x+40,242$ and the correlation coefficient was 0.9988 , which indicated that there was a good linear relationship between the concentration and the corresponding peak area in the range of $1-100 \mu \mathrm{g} / \mathrm{mL}$. The concentration of clove extract was $10 \mathrm{mg} / \mathrm{mL}$; therefore, the detection of eugenol was $4.43 \mathrm{mg} / \mathrm{mL}$ and the content of eugenol in clove extract was about $44.3 \%$.

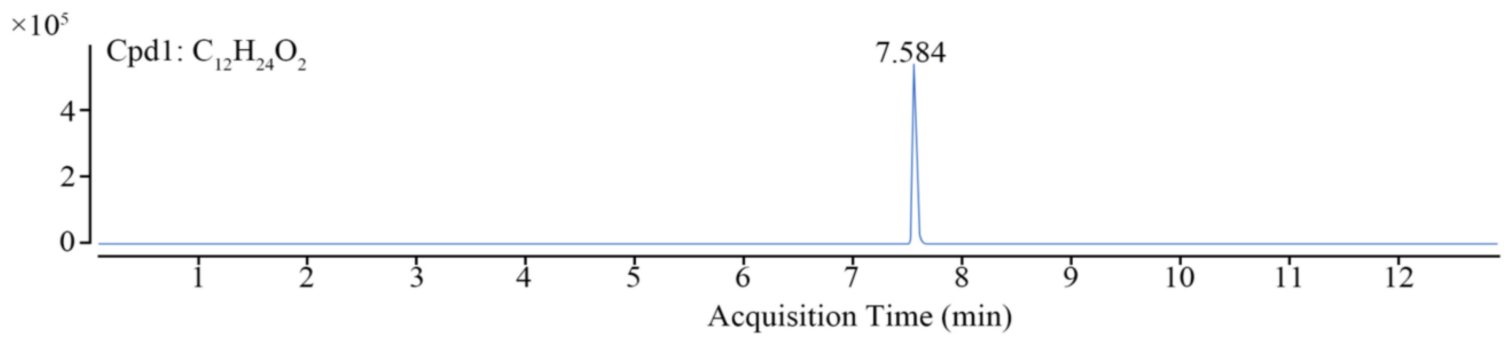

(a)

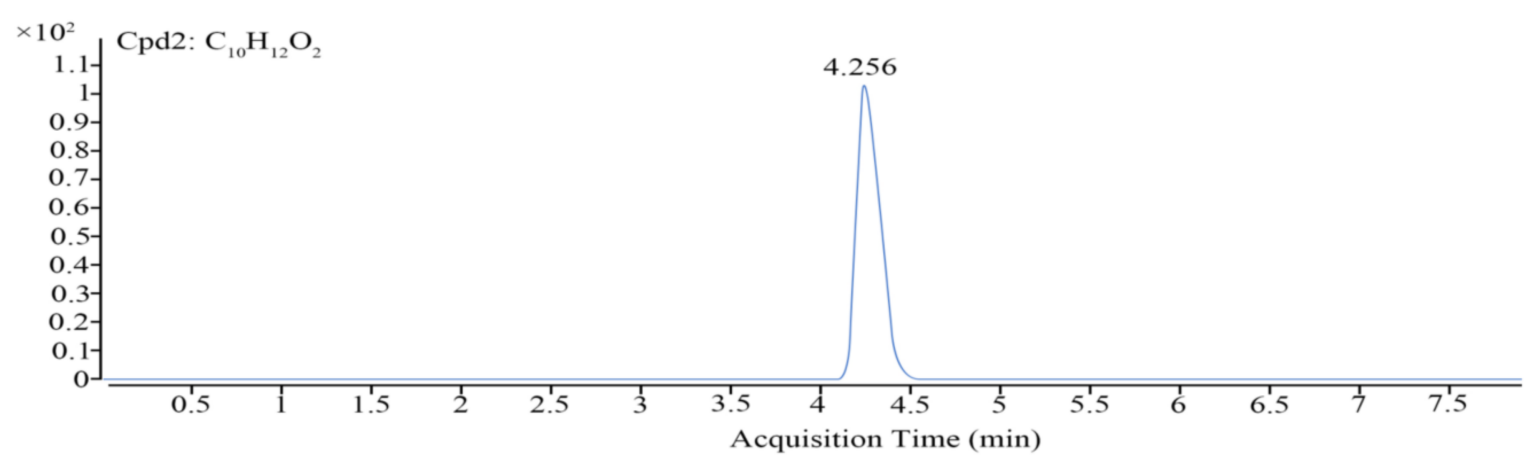

(b)

Figure 5. LC-MS analysis. (a) Quantitative ion chromatogram of lauric acid; (b) Quantitative ion chromatogram of eugenol.

\section{Discussion}

Rice sheath blight is one of the main diseases of rice. This disease serious affects rice yield. There are few highly resistant rice varieties [18]. Thus, chemical control is the main approach to disease control. The use of chemical agents approach is hindered by the " $3 R^{\prime}$ problem. The impact on the environment and human health is a research priority. Among the numerous fungicides used to control rice sheath blight, jinggangmycin and its related improved products occupy an important market position. They have become the agricultural microbial antibiotics with the highest sales [19]. However, negative impacts have spurred international appeals for prohibition. Therefore, the development of new biological pesticides to replace jinggangmycin has become a priority.

Plants are an important source of botanical fungicides and an important part of the development of environmentally harmonious pesticides and biorational pesticides. Advantages of plant-derived fungicides include pronounced efficiency, low toxicity, ease of degradation, and lack of development of resistance [20]. Compounds isolated from plant extracts, such as steroids, tannins, flavonoids, alkaloids, and saponins, have antibacterial activ- 
ity [21]. Venkateswarlu et al. [22] reported that $2 \%$ preparations derived from Zanthoxylum bungeanum and Andrographis paniculata had good inhibitory effects on the sclerotium of stem rot. Lu et al. [23] studied the antifungal activities of the crude extracts of four Chinese herbal medicines and found that the minimum inhibitory concentrations of gallnut and coca seed were both $3.9 \mu \mathrm{g} / \mathrm{mL}$, with strong inhibitory effects on Candida albicans and Cryptococcus neoformans. Serrano et al. [24] treated sweet cherry with thymol, eugenol, and menthol, and found that the number of mold, yeast, and aerobic mesophilic bacteria decreased, especially mold and yeast.

In this study, 24 plant-derived extracts were selected to study the biological activity of $R$. solani. Only a few of the extracts displayed inhibitory activity on $R$. solani. In particular, the ethanol extracts of gallnut and clove at $10 \mathrm{mg} / \mathrm{mL}$ showed strong inhibitory effects followed by the ethanol extracts of $A$. sinensis and C. cassia. The bacteriostatic rate of $50 \%$ increased as the extract concentration increased. The ethanol extracts of gallnut and clove displayed good antibacterial effects $\left(\mathrm{EC}_{50}\right.$ of 41.84 and $21.68 \mu \mathrm{g} / \mathrm{mL}$, respectively).

The gallnut and clove extracts displayed inhibitory effects on the mycelia of rice sheath blight. SEM showed that both extracts produced wrinkles on the surface of the mycelium and caused varying degrees of damage to the secondary growth point of the mycelium. TEM was used to observe the internal structures of the mycelium cells. After treatment with gallnut extract, the mitochondria in the mycelium were swollen and broken, the nuclei of cells were disintegrated, and protoplasts were aggregated. Gallnut reportedly had a strong inhibitory effect on the $\beta$-galactosidase activity of Agrobacterium tumefaciens strain A136, with an inhibition rate of 33.20\% [25]. Gallnut extract also inhibited enamel demineralization in vitro [26], and the survival of Vibrio parahaemolyticus and Listeria monocytogenes in cooked shrimp and raw tuna [27]. The most prevalent compound on gallnut is tannic acid $[28,29]$, but its inhibitory effect on rice sheath blight hyphae is not significant. Lauric acid, another component of gallnut, is the most active compound for inhibiting $R$. solani hyphae growth (this part of the data will be published at a later date). Li et al. [27,30] found that citral extracted from Litsea cubeba could destroy the integrity of the cell wall and membrane permeability of rice blast, resulting in physiological changes and cytotoxicity. Presently, after treatment with clove extract, organelles in the mycelia of $R$. solani were completely degraded, cell contents were aggregated, and the cell wall was ablated. Eugenol is one of the main components of clove. The compound has a minimal inhibitory concentration of $200 \mu \mathrm{g} / \mathrm{mL}$ against mycelia of Phytophthora nicotianae. Eugenol can significantly destroy the cell membrane of mycelium without affecting the integrity of the spore membrane [31]. Pasqua et al. [32] and Helander et al. [33] proposed that eugenol could inhibit the production of essential enzymes in bacteria and cause cell wall damage. Zambonelli et al. [34] reported that the cell morphology of fungal hyphae of $R$. solani and Colletotrichum gloeosporioides was characterized by increased cytoplasmic vacuoles, accumulation of liposomes, plasma membrane fluctuations, and mitochondrial and endoplasmic reticulum changes. Eugenol is also a volatile essential oil. It can ablate intracellular organelles of $R$. solani, similar to the mode of action of thymol on fungal cells. The site of action of eugenol on mycelial cells is the cell membrane $[35,36]$, yet the ultrastructural damage of the mycelia of rice sheath blight mainly involves intracellular organelles.

When the concentrations of gallnut and clove ethanol extracts were $1000 \mu \mathrm{g} / \mathrm{mL}$, the control effects were $45.8 \%$ and $37.88 \%$, respectively. The effect of the gallnut extract was better than that of the clove extract. This was likely because the clove ethanol extract contains the volatile component clove phenol $\mathrm{C}_{10} \mathrm{H}_{12} \mathrm{O}_{2}$ (2-methoxy-4-allylphenol). It adopts an allyl chain structure to replace o-methoxyphenol. It is chemically unstable; thus improved stability will be necessary for its optimal use in control of plant diseases [35-37]. Gallnut extract displayed a good protective effect against rice sheath blight in vivo. Investigations of the effect of eugenol on $P$. nicotianae in vivo revealed an effective reduction of the incidence of P. nicotianae and a good control effect in the field [31]. Acorus gramineus extract had good antibacterial activity, and the control effect on rice sheath blight was $25 \%$ at $500 \mu \mathrm{g} / \mathrm{mL}$ [38]. Khoa et al. [39] reported that seed soaking and spraying extracts 
from dry or fresh leaves of Chromolaena odorata can reduce the occurrence of sheath blight. The collective observations conclusively indicate that plant extracts can effectively control crop diseases.

\section{Materials and Methods}

4.1. Materials

4.1.1. Isolation and Identification of Rice Sheath Blight Pathogen

The Rhizoctonia solani AG1 IA strain of rice sheath blight was isolated from infected rice. The strain was identified by the laboratory of the Crop Protection Institute of Guizhou University. R. solani was inoculated into potato dextrose agar (PDA) (Shanghai Aladdin Biochemical Technology Co., Ltd., Shanghai, China) and incubated at $25^{\circ} \mathrm{C}$ and $150 \mathrm{rpm}$ for 3 days, and stored at $-80^{\circ} \mathrm{C}$.

\subsubsection{Collection of Plant-Derived Materials}

Raw materials of 24 species were purchased in September 2018 from YiPing Company, Huaxi District, Guiyang City, Guizhou, China. Details are provided in Table 1.

\subsection{Methods}

\subsubsection{Collection and Preparation of Plant-Derived Extracts}

The crude plant extract was obtained using the organic solvent ethanol immersion method modified from a previous study [16]. The air-dried plant was ground into a powder with a shredder. One hundred grams of the powder was added to $250 \mathrm{~mL}$ anhydrous ethanol (Shanghai Aladdin Biochemical Technology Co., Ltd., Shanghai, China) at $50{ }^{\circ} \mathrm{C}$ for $2 \mathrm{~h}$ ultrasonic extraction. The extraction was repeated three times. The combined clear supernatant was filtered using a Buchner funnel and then steamed with a rotary evaporator at $46^{\circ} \mathrm{C}$ in water bath solvent. The crude extract was stored in a refrigerator at $4{ }^{\circ} \mathrm{C}$.

4.2.2. In Vitro Evaluation of Rice Sheath Blight Inhibition Activity of Plant-Derived Extracts

The inhibitory effect of the plant-derived ethanol extract on the growth of rice sprigs was determined by the growth rate of mycelia. The herbal extract for testing was first weighed and then completely dissolved in $200 \mu \mathrm{L}$ of aqueous ethanol. The final concentration of the solution was adjusted to $10 \mathrm{mg} / \mathrm{mL}$ with sterile water. The solution was added to PDA medium, which was cooled to approximately $50{ }^{\circ} \mathrm{C}$ in a $1: 9$ volume ratio. The volume was poured into a petri dish and solidified. The procedure was repeated three times, with the same proportion of sterile water and PDA. A $5 \mathrm{~mm}$ punch was used to create blocks from plates cultured with the $R$. solani AG1 IA. The punched blocks were carefully added to the center of the drug-containing culture using an inoculation needle, with the mycelium facing down, with one piece added per dish. The samples were cultured for 3 days at $25^{\circ} \mathrm{C}$ in a constant-temperature Foster box. The diameter of the bacteria was measured by the cross-cutting method. The average value was determined and the antibacterial rate was calculated as follows:

$$
\text { Inhibition rate }(\%)=\frac{M c-M t}{M c-0.5} \times 100
$$

where $M c$ and $M t$ represent the mycelial growth diameter in control, gallnuts-treated, and cloves-treated conditions, respectively. The $\mathrm{EC}_{50}$ (effective dose for $50 \%$ inhibition) values were estimated statistically by probit analysis with the probit package of SPSS 22.0 software (SPSS Inc., Chicago, IL, USA) [40].

\subsubsection{Determination of Eugenol and Lauric Acid Content}

Determination of eugenol content: Analysis of eugenol content was performed on a Waters UPLC BEHC18. Water with 0.1\% $(v / v)$ ammonia (A) (Wuhan Chuangsheng Chemicals Co. Ltd., Wuhan, China) and acetonitrile (B) (Wuhan Chuangsheng Chemicals Co. Ltd., 
Wuhan, China) were used as solvents at a flow rate of $0.5 \mathrm{~mL} / \mathrm{min}$. The substances were eluted with a linear gradient as follows: $0.5 \mathrm{~min}, 25 \% \mathrm{~B} ; 0.5-2.5 \mathrm{~min}, 5 \% \mathrm{~B} ; 2.5-3 \mathrm{~min}, 5 \% \mathrm{~B}$, 3-4 $\mathrm{min}, 5 \% \mathrm{~B} ; 4-5 \mathrm{~min}, 95 \% \mathrm{~B}$; 5-6 $\mathrm{min}, 95 \% \mathrm{~B} ; 6-7 \mathrm{~min}, 25 \% \mathrm{~B} ; 7-8 \mathrm{~min}, 25 \%$ B. The ion source was an electrospray ion source in negative ion mode $\left(\mathrm{ESI}^{-}\right)$. Multi-reaction monitoring mode (MRM), capillary $1.48 \mathrm{kV}$, cone voltage $29 \mathrm{~V}$, collision gas flow rate $0.15 \mathrm{~mL} / \mathrm{min}$, the multi-reaction monitoring ion pair and conditions are shown in Table 5. The standard curve of eugenol was drawn according to the mass concentration. The extracted eugenol samples were treated according to the detection method, and the eugenol content was calculated according to the standard curve.

Table 5. MRM ion pairs and mass spectral parameters for eugenol and lauric acid.

\begin{tabular}{cccccc}
\hline Compounds & ESI & Parent $(\mathbf{m} / \mathbf{z})$ & Daughter $(\mathbf{m} / \mathbf{z})$ & Cone voltage/V & Colision energy/eV \\
\hline \multirow{2}{*}{ eugenol } & - & \multirow{2}{*}{163} & 148 & 29 & 13 \\
& & & 121 & & 24 \\
\hline \multirow{2}{*}{ lauric acid } & - & 259 & 245 & 75 & 30 \\
& & & 199 & & 45 \\
\hline
\end{tabular}

Determination of lauric acid content: A Waters UPLC BEHC18 column was used, with an injection volume of $10 \mu \mathrm{L}$ and a flow rate of $0.5 \mathrm{~mL} / \mathrm{min}$. The mobile phase was $0.1 \%$ formic acid water, the mobile phase B was methanol, gradient elution was used, and the gradient elution procedure was as follows: $1 \mathrm{~min}, 10 \% \mathrm{~B} ; 1-3 \mathrm{~min}, 10 \% \mathrm{~B} ; 3-12 \mathrm{~min}$, $90 \% \mathrm{~B}, 12-13 \mathrm{~min}, 10 \% \mathrm{~B}$. The ion source was the electrospray ion source in negative ion mode $\left(\mathrm{ESI}^{-}\right)$. Multi-reaction monitoring mode (MRM), capillary $1.48 \mathrm{kV}$, cone voltage $75 \mathrm{~V}$, collision gas flow rate $0.15 \mathrm{~mL} / \mathrm{min}$, the multi-reaction monitoring ion pair and conditions are shown in Table 5. The standard curve of lauric acid was drawn according to the mass concentration. The extracted eugenol samples were treated according to the detection method, and the lauric acid content was calculated according to the standard curve.

\subsubsection{Indoor Toxicity Determination of Plant-Derived Extracts}

Based on the preceding results, clove and gallnut (Wuhan Chuangsheng Chemicals Co. Ltd., Wuhan, China), which displayed 100\% antibacterial rates, were selected for further toxicity tests. Clove extracts were 10, 20,30, 40, and $50 \mu \mathrm{g} / \mathrm{mL}$. Gallnut extracts were set as $15,30,45,60$, and $75 \mu \mathrm{g} / \mathrm{mL}$. The detailed antibacterial effects were also analyzed.

\subsubsection{Scanning Electron Microscopy (SEM)}

R. solani AG1 IA was cultured on medium containing 0 or $36.34 \mu \mathrm{g} / \mathrm{mL}$ (EC75 value) of clove ethanol extract and $72.59 \mu \mathrm{g} / \mathrm{mL}$ (EC75 value) gallnut ethanol extract for 3 days. Rectangular blocks $(0.5 \mathrm{~cm} \times 0.3 \mathrm{~cm})$ from the edge of the mycelium were placed in a centrifuge tube with $1 \mathrm{~mL}$ of $25 \%$ dialdehyde fixation fluid. Three blocks were taken for each treatment. Each sample was suctioned repeatedly with a $50 \mathrm{~mL}$ syringe until the bubbles on the surface of the mycelium disappeared. The centrifuge tube was sealed and stored overnight at $4{ }^{\circ} \mathrm{C}$. After suction, the retaining fluid was carefully rinsed three times with $0.1 \mathrm{M}$ Phosphate Buffer Solution (PBS) for $10 \mathrm{~min}$ each time. Then, $0.5 \mathrm{~mL}$ of $1 \%$ nitric acid fixative was added within $2 \mathrm{~h}$. Each sample was washed three times with PBS. Ethanol solutions of $30 \%, 50 \%, 70 \%, 80 \%$, and $90 \%$ were used for dehydration for $10 \mathrm{~min}$ each time, followed by dehydration twice with waterless ethanol for $10 \mathrm{~min}$ each time. After dehydration, the specimens were dried in a freeze drier (LGJ-10D; Beijing Fourth Ring Scientific Instrument Co., Ltd., Beijing, China), and sputter-coated with gold. Microscopy was performed using an SEM (S-3400N; Hitachi, Tokyo, Japan) operated at an accelerating voltage of $20 \mathrm{kV}$. Controls consisted of untreated mycelia, which were prepared in parallel with experimental samples. 


\subsubsection{Transmission Electron Microscopy (TEM)}

The mycelium collected as described above was poured into a centrifuge tube with $1 \mathrm{~mL}$ of $2.5 \%$ dialdehyde fixation fluid. The tube was sealed and incubated overnight at $4{ }^{\circ} \mathrm{C}$. After the remaining fluid was carefully suctioned off, the sample was rinsed three times with $0.1 \mathrm{M}$ PBS, for $10 \mathrm{~min}$ each time. Then, $0.5 \mathrm{~mL}$ of $1 \%$ nitric acid fixative was added within $2 \mathrm{~h}$. They were then washed three times with PBS, and ethanol solutions with concentrations of $30 \%, 50 \%, 70 \%, 80 \%$, and $90 \%$ were dehydrated for 10 min each time, and then dehydrated twice with waterless ethanol for 20 min each time. A mixture of acetone and resin with different concentration ratios (3:1, 1:1, 1:3 v/v) was successively used for infiltration for $3 \mathrm{~h}$ each time. This was followed by treatment with pure resin overnight. After polymerization at $70^{\circ} \mathrm{C}$ for $24 \mathrm{~h}$, the embedded samples were removed for preparation of ultra-thin sections. The sections were stained with lead citrate and uranium diacetate, dried, and observed by TEM (JEM-F200; JEOL, Tokyo, Japan).

\subsubsection{Protective Effect of Plant-Derived Extracts on Rice In Vivo}

Rice was sown in a plastic basin with a diameter of $16 \mathrm{~cm}$ and a height of $12 \mathrm{~cm}$. At the tillering stage, the ethanol extracts of gallnut and clove were diluted with a $0.1 \%$ Tween 80 emulsified water solution to 200, 400, 600, 800, or $1000 \mu \mathrm{g} / \mathrm{mL}$. Each preparation was sprayed on rice plants with $0.1 \%$ Tween 80 emulsified water solution as the blank control. After $24 \mathrm{~h}$ of spraying, the rice sprigs were inoculated with R. solani AG1 IA embedded in a cake $(0.6 \mathrm{~cm}$ in diameter) on the leaves of the penultimate leaf of the plant. Twenty plants were inoculated per treatment and were cultured in an incubator at a temperature of $25 \pm 2{ }^{\circ} \mathrm{C}$, relative humidity of $90 \%$, and $12 \mathrm{~h}$ of lighting time. After 7 days of inoculation, the data were acquired according to the classification standard of rice sheath blight, the average value was determined, and the control effect was calculated.

\subsubsection{Data Processing and Analysis}

The growth inhibition rate was converted to an inhibition probability value. The toxicity regression equation, inhibition medium concentration $\left(\mathrm{EC}_{50}\right)$, and correlation coefficient $(\mathrm{R})$ were calculated using the logarithm of extract concentration and inhibition probability value. Excel software and SPSS statistical software package release 22.0 (SPSS Inc., Chicago, IL, USA) were used to process the relevant data.

\section{Conclusions}

Plant-sourced fungicides are a class of plant antibacterial substances or compounds that induce plant defenses. They can kill or inhibit the growth of target pathogens efficiently with no or low toxicity, degrade readily, and do not prompt development of resistance, which has led to their widespread use. In this study, the growth inhibition effect of 24 plant-sourced ethanol extracts on hyphae of rice sheath blight was studied. Ethanol extracts of gallnuts and cloves inhibited the growth of bacteria by up to $100 \%$. Indoor toxicity measurement results showed that the effective concentrations of gallnut and clove constituents reached $39.23 \mu \mathrm{g} / \mathrm{mL}$ and $18.82 \mu \mathrm{g} / \mathrm{mL}$, respectively. The results showed that protection from Rhizoctonia solani reached $46.8 \%$ for gallnut and $37.88 \%$ for clove in water emulsions of $1000 \mu \mathrm{g} / \mathrm{mL}$ gallnut and clove in the presence of $0.1 \%$ Tween 80 . The protective effects of gallnut were significantly stronger than those of clove on rice sheath blight. Although these extracts inhibit the mycelium of rice sheath blight and improve plant defenses, they have not yet been developed as suitable substitutes for commercial chemical fungicides for application in rice agriculture. To achieve this, optimized field trials are needed to determine the optimal application doses in paddy fields. 
Author Contributions: The listed authors contributed to this work as described in the following: Conceptualization, M.L. gave the concepts of this work, designed the whole experiments, and provided financial support; J.W. did the experiments and prepared the original draft; X.H., C.Y., X.W., and R.L. did part of the experiment and data creation; M.L., R.L., X.H., C.Y., and X.W. reviewed and edited this manuscript; X.H., C.Y., and X.W. did the methodology and formal analysis. All authors have read and agreed to the published version of the manuscript.

Funding: This study was supported by National Natural Science Foundation of China (No. 31701816, 31460480), the National Key R \& D Program of China (No. 2016YFD0200500), Science and Technique Foundation of Guizhou Province (No. [2017]1038), and Technology Platform and Talent Team Foundation of Guizhou province (No. [2017]5788).

Institutional Review Board Statement: Not applicable.

Informed Consent Statement: Not applicable.

Data Availability Statement: Not applicable.

Acknowledgments: We greatly appreciate the funding support for this research provided by the National Natural Science Foundation of China (No. 31701816, 31460480), the National Key R \& D Program of China (No. 2016YFD0200500), Science and Technique Foundation of Guizhou Province (No. [2017]1038), and Technology Platform and Talent Team Foundation of Guizhou province (No. [2017]5788) for financial support.

Conflicts of Interest: The authors declare that they have no conflicts of interests.

Sample Availability: Samples of the compounds are not available from the authors.

\section{References}

1. Wu, W.; Shah, F.; Shah, F.; Huang, J.L. Rice sheath blight evaluation as affected by fertilization rate and planting density. Australas Plant. Path. 2015, 44, 183-189. [CrossRef]

2. Wu, W.; Liao, Y.C.; Shah, F.; Nie, L.X.; Peng, S.B.; Cui, K.H.; Huang, J.L. Plant growth suppression due to sheath blight and the associated yield reduction under double rice-cropping system in central China. Field Crops Res. 2013, 144, 268-280. [CrossRef]

3. Zheng, L.; Liu, H.Q.; Zhang, M.L.; Cao, X.; Zhou, E.X. The comnplete genomic sequence of a novel mycovirus from Rhizoctonia solani AG-1 1A strain B275. Arch. Virol. 2013, 158, 1609-1612. [CrossRef] [PubMed]

4. Srinivasachary, W.L.; Savary, S. Resistance to rice sheath blight (Rhizoctonia solani Kühn) [(teleomorph: Thanatephorus cucumeris (A.B. Frank) Donk.] disease: Current status and perspectives. Euphytica 2011, 178, 1-22. [CrossRef]

5. Singh, P.; Mazumdar, P.; Harikrishna, J.A.; Babu, S. Sheath blight of rice: A review and identification of priorities for future research. Planta 2019, 250, 1387-1407. [CrossRef]

6. Ou, S.H. Rice Diseases, 2nd ed.; Commonwealth Mycological Institute: Kew Surrey, UK, 1985; pp. $109-201$.

7. Basu, A.; Chowdhury, S.; Chaudhuri, R.T.; Kundu, S. Differential behaviour of sheath blight pathogen Rhizoctonia solani in tolerant and susceptible rice varieties before and during infection. Plant. Pathol. 2016, 65, 1333-1346. [CrossRef]

8. Singh, D.; Seo, M.J.; Kwon, H.J.; Rajkarnikar, A.; Kim, K.R.; Kim, S.O.; Suh, J.W. Genetic Localization and Heterologous Expression of Validamycin Biosynthetic Gene Cluster Isolated from Streptomyces hygroscopicus var. 1imoneus KCCM 11405(IFO 12704). Gene 2006, 376, 13-23. [CrossRef] [PubMed]

9. Zhang, S.; Xu, W.X.; Xue, Y.G.; Chen, X.Y.; Wang, J.R. A Preliminary study on the Sensitivity of Rice Sheath Blight Fungi (Rhizoctonia solani) to Jinggangmycin in Zhengzhou County of Henan Province. Chin. J. Biol. Control. 1995, 11, 171-173, (In Chinese with English Abstract). [CrossRef]

10. Müller, J.; Boller, T.; Wiemken, A. Effect of Validamycin A a potent trehalase inhibitor, and phytohomones on trehalose metabolism in roots and nodules of soybean and cowpea. Planta 1995, 197, 362-368. [CrossRef]

11. Wu, J.; Xi, Y.D.; Li, H.H.; Wang, L.X.; Peng, H.X. Monitoring of Resistance of Thenatephorus Cucumeris to Jinggangmysin in Sichuan. Southwest China J. Agric. Sci. 2015, 6, 2501-2504, (In Chinese with English Abstract). [CrossRef]

12. Chen, Y.; Yao, J.; Yang, X.; Zhang, A.F.; Gao, T.C. Sensitivity of Rhizoctonia solani causing rice sheath blight to fluxapyroxad in China. Eur. J. Plant. Pathol. 2014, 140, 419-428. [CrossRef]

13. Ji, Y.R.; Yang, Q.L.; Dong, Y.; Ma, Z.J.; Liu, S.X.; Zhang, Z.H.; Guan, X.J. Research and Application on nematicidal activity of the Leguminosae plants. J. Anhui Agri. Sci. 2014, 42, 8884-8886. [CrossRef]

14. Grange, M.; Ahmed, S. Handbook of Plants with Pest-Control Properties; Wiley-Interscience: New York, NY, USA, 1988 ; p. 65.

15. Buckingham, J. Dictionary of Natural Products on DVD; Version 29.2; Chapman and Hall/CRC: Boca Raton, FL, USA, 2019; pp. 102-167.

16. Fogliani, B.; Bouraïma-Madjebi, S.; Medevielle, V.; Pineau, R. Screening of 50 Cunoniaceae species from New Caledonia for antimicrobial properties. N. Z. J. Bot. 2002, 40, 511-520. [CrossRef] 
17. Ojala, T.; Rames, S.; Haansuu, P.; Vuorela, H.; Hiltunen, R.; Haahtela, K.; Vuorela, P. Antimicrobial activity of some coumarin containing herbal plants growing in Finland. J. Ethnopharmacol. 2000, 73, 299-305. [CrossRef]

18. Srinivasan, D.; Nathana, S.; Suresh, T.; Perumasamy, P.L. Antimicrobial activity of certain Indian medicinal plants used in folkloric medicine. J. Ethnopharmacol. 2001, 74, 217-220. [CrossRef]

19. Padaria, J.C.; Tarafdar, A.; Raipuria, R.; Lone, S.A.; Gahlot, P.; Shakil, N.A.; Kumar, J. Identification of phenazine-1-carboxylic acid gene (phc CD) from Bacillus pumilus MTCC7615 and its role in antagonism against Rhizoctonia solani. Basic Microbiol. 2016, 56, 999-1008. [CrossRef]

20. Li, A.H.; Xu, X.P.; Dai, Z.Y.; Chen, Z.X.; Li, B.J.; Zhang, H.X.; Pan, X.B. Analysis of Resistance to Rice Sheath Blight for Transgenic line of rice. Chin. J. Rice Sci. 2003, 17, 302-306.

21. Rajendra, P.; Ayub, K.; Wendy-Ann, I.; Wayne, G.; Duraisamy, S. Plant extracts, bioagents and new generation fungicides in the control of rice sheath blight in Guyana. Crop Prot. 2019, 119, 30-37. [CrossRef]

22. Venkateswarlu, N.; Vijaya, T.; Suresh, B.D.; Chandra, M.K.; Pragathi, D.; Anitha, D.; Sreeramulu, A. In Vitro Inhibitory Effects of Medicinal Plants Extracts on Sclerotium Oryzae- a Fungi Causing Stem Rot Disease in Paddy. Int. J. Pharm. Biol. Sci. 2013, 3, 147-151.

23. Lu, R.Y.; Wu, J.; Jiang, Y.Y. Study on the Antifungal Activity of Four Kinds of Traditional Chinese Medicine Extracts. Guangdong Chem. 2020, 22, 49-52, (In Chinese with English Abstract).

24. Serrano, M.; Martínez-Romero, D.; Castillo, S.; Guillén, F.; Valero, D. The use of natural antifungal compounds improves the beneficial effect of MAP in sweet cherry storage. Innov. Food Sci. Emerg. 2005, 1, 115-123. [CrossRef]

25. Zhang, Y.; Djakpoa, O.; Xie, Y.F.; Guo, Y.H.; Yu, H.; Cheng, Y.L.; Qian, H.; Shi, R.; Yao, W.R. Anti-quorum sensing of Galla chinensis and Coptis chinensis on bacteria. Food Sci. Technol. 2019, 101, 806-811. [CrossRef]

26. Huang, X.L.; Liu, M.D.; Li, J.Y.; Zhou, X.D.; Cate, J.M.T. Chemical composition of Galla chinensis extract and the effect of its main component(s) on the prevention of enamel demineralization in vitro. Int. J. Oral Sci. 2012, 4, 146-151. [CrossRef]

27. Wu, J.; Jahncke, M.L.; Eifert, J.D.; O'Keefe, S.F.; Welbaum, G.E. Pomegranate peel (Punica granatum L) extract and Chinese gall (Galla chinensis) extract inhibit Vibrio parahaemolyticus and Listeria monocytogenes on cooked shrimp and raw tuna. Food Control 2016, 59, 695-699. [CrossRef]

28. Tian, F.; Li, B.; Ji, B.; Zhang, G.Z.; Luo, Y.C. Identification and structure-activity relationship of gallotannins separated from Galla chinensis. LWT Food Sci. Technol. 2009, 42, 128-1295. [CrossRef]

29. Tian, F.; Li, B.; Ji, B.P.; Yang, J.H.; Zhang, G.Z.; Chen, Y.; Luo, Y.C. Antioxidant and antimicrobial activities of consecutive extracts from Galla chinensis: The polarity affects the bioactivities. Food Chem. 2009, 113, 173-179. [CrossRef]

30. Li, R.Y.; Wu, X.M.; Yin, X.H.; Long, Y.H.; Li, M. Naturally produced citral can significantly inhibit normal physiology and induce cytotoxicity on Magnaporthe grisea. Pestic. Biochem. Physiol. 2014, 118, 19-25. [CrossRef] [PubMed]

31. Jing, C.L.; Gou, J.Y.; Han, X.B.; Wu, Q.; Zhang, C.S. In vitro and in vivo activities of eugenol against tobacco black shank caused by Phytophthora nicotianae. Pestic. Biochem. Physiol. 2017, 142, 148-154. [CrossRef]

32. Pasqua, D.R.; Betts, G.; Hoskins, N.; Edwards, M.; Ercolini, D.; Mauriello, G. Membrane toxicity of antimicrobial compounds from essential oils. J. Agric. Food Chem. 2007, 55, 4863-4870. [CrossRef] [PubMed]

33. Helander, I.M.; Alakomi, H.L.; Latva-Kala, K.; Mattila-Sandholm, T.; Pol, I.; Smid, E.J.; Gorris, L.G.M.; Wright, A.V. Characterization of the Action of Selected Essential Oil Components on Gram-Negative Bacteria. J. Agric. Food Chem. 1998, 46, 3590-3595. [CrossRef]

34. Zambonelli, A.D.; D'Aulerio, A.Z.; Severi, A.; Benvenuti, S.; Maggi, L.; Bianchi, A. Chemical Composition and Fungicidal Activity of Commercial Essential Oils of Thymus vulgaris L. J. Essent. Oil Res. 2004, 16, 69-74. [CrossRef]

35. Mallavarapu, G.R.; Ramesh, S.; Chandrasekhara, R.S.; Rajeswara Rao, B.R.; Kaul, P.N.; Bhattacharya, A.K. In vestigation of the essential oil of cinnamon leaf grown at Bangalore and Hyderabad. Flavour. Frag. J. 1995, 10, 239-242. [CrossRef]

36. Amrania, S.E.; Lalamib, A.E.O.; Zoubic, Y.E.; Moukhafia, K.; Bouslamtia, R.; Lairinia, S. Evaluation of antibacterial and antioxidant effects of cinnamon and clove essential oils from Madagascar. Mater. Today Proc. 2019, 13, 762-770. [CrossRef]

37. Briozzo, J.; Núncez, L.; Chirife, J.; Herszage, L.; D’aquino, M. Antimicrohial activity of clove oil dispersed in a concentrated sugar solution. J. Appl. Microbiol. 1989, 66, 69-75. [CrossRef]

38. Lee, S.E.; Park, B.S.; Kim, M.K.; Choi, W.S.; Kim, H.T.; Cho, K.Y.; Lee, S.G.; Lee, H.S. Fungicidal activity of pipernonaline, a piperidine alkaloid derived from long pepper, Piper longum L., against phytopathogenic fungi. Crop Prot. 2001, 20, 523-528. [CrossRef]

39. Khoa, N.D.; Thuy, P.T.H.; Thuy, T.T.T.; Collinge, D.B.; Jørgensen, H.J.L. Disease-reducing effect of Chromolaena odorata extract on sheath blight and other rice diseases. Phytopathology 2011, 101, 231-240. [CrossRef] [PubMed]

40. Gao, X.B.; Guo, C.; Li, M.; Li, R.Y.; Wu, X.M.; Hu, A.L.; Hu, X.F.; Mo, F.X.; Wu, S. Physicochemical Properties and Bioactivity of a New Guar Gum-Based Film Incorporated with Citral to Brown Planthopper, Nilaparvata lugens (Stål) (Hemiptera: Delphacidae). Molecules 2020, 25, 2044. [CrossRef] 